\title{
Effect of zooplankton-mediated trophic cascades on marine microbial food web components (bacteria, nanoflagellates, ciliates)
}

\section{Eckart Zöllner}

Max Planck Institute for Limnology, August-Thienemann-Straße 2, 24306 Plön, Germany; IFM-GEOMAR, Leibniz Institute of Marine Sciences, Düsternbrooker Weg 20, 24105 Kiel, Germany

Hans-Georg Hoppe and Ulrich Sommer

IFM-GEOMAR, Leibniz Institute of Marine Sciences, Düsternbrooker Weg 20, 24105 Kiel, Germany

\section{Klaus Jürgens ${ }^{1}$}

Max Planck Institute for Limnology, August-Thienemann-Straße 2, 24306 Plön, Germany; Leibniz Institute for Baltic Sea Research Warnemünde, Seestraße 15, 18119 Rostock, Germany

\begin{abstract}
To examine the grazing effects of copepod-dominated mesozooplankton on heterotrophic microbial communities, four mesocosm experiments using gradients of zooplankton abundance were carried out at a coastal marine site. The responses of different protist groups (nanoflagellates, ciliates) and bacterioplankton in terms of abundance and additionally, for bacteria, diversity, production, and exoenzymatic activity, were monitored during 1 week of incubation. Independent of the initial experimental abiotic conditions and the dominating copepod species, zooplankton caused order-of-magnitude changes in microbial functional groups in a clear community-wide four-link trophic cascade. The strongest predatory effects were observed for protist concentrations, thus generating inverse relationships between mesozooplankton and ciliates and between ciliates and nanoplankton. Copepod grazing effects propagated even further, not only reducing the abundance, production, and hydrolytic activity of bacterioplankton but also increasing bacterial diversity. The overall strength of this trophic cascade was dampened with respect to bacterial numbers, but more pronounced with respect to bacterial diversity and activity. High predation pressure by heterotrophic nanoflagellates, realized at the highest copepod abundance, was probably the underlying mechanism for these structural changes in the bacterial assemblages. Our results thus suggest a mechanism by which changes in higher trophic levels of marine plankton indirectly affect prokaryotic assemblages and microbially mediated ecosystem functions.
\end{abstract}

Microorganisms mediate most biogeochemical processes in the oceans and their activities are influential in element cycling on a global scale. In contrast to the accruing knowledge of prokaryotic diversity and functions in the ocean, much less is known about how microbial communities interact with the pelagic food web. Similar to other trophic levels, bacterioplankton communities are regulated by bottom-up factors, e.g., nutrient limitation, and by topdown factors, e.g., protist predation and viral infection (Thingstad 2000). Several trophic levels are organized

${ }^{1}$ Corresponding author (klaus.juergens@io-warnemuende.de).

\section{Acknowledgments}

We thank all members of the food web team and the technical staff of the Max Planck Institute for Limnology (Plön) and the IFM-GEOMAR, Leibniz Institute of Marine Sciences (Kiel) for help in the field and in the laboratory; our colleagues Y. Olsen, A. Neyts, N. Tokle, and Ø. Leiknes for their support during the mesocosm experiments in Norway; and J. Gasol, R. Massana, M. Boersma, G. Jost, and J. Grey for comments on earlier versions of the manuscript.

This study was financed by the German Science Foundation (DFG grants JU367/4-1, 4-2) and supported by the Trondheim Marine Systems Research Infrastructure and the European Commission's Improving Human Potential Programme (Project COMEZOO) through contract HPRI-1999-CT-00060. within the pelagic microbial food web. The main predators of planktonic prokaryotes (picoplankton, $0.2-2 \mu \mathrm{m}$ ) are small heterotrophic and mixotrophic nanoflagellates, mainly in the size range of 3-5 $\mu \mathrm{m}$ (Fenchel 1986; Sherr and Sherr 2002). There is plentiful evidence that ciliates are important omnivorous grazers of nanoplankton $(2-20 \mu \mathrm{m})$ and their micro-sized forms $(>20 \mu \mathrm{m})$ especially are often the dominating herbivores in marine systems (Sherr and Sherr 2002).

Mesozooplankton $(0.2-2 \mathrm{~mm}$ in size), which prey on phytoplankton as well as on different heterotrophic protistan groups, connect the microbial food web with the classical algae-zooplankton-fish food chain (Sanders and Wickham 1993; Kiørboe 1997). For example, copepods, which constitute the majority of the mesozooplankton in the oceans (Verity and Smetacek 1996), are known to be efficient predators on planktonic ciliates (Calbet and Saiz 2005). The effect of zooplankton on microbial food webs has been studied extensively in freshwater systems (Wickham 1998; Zöllner et al. 2003), where copepods and cladocerans may dominate the mesozooplankton. Marine studies have focused mainly on the copepod-ciliate link (Levinsen et al. 2000; Broglio et al. 2004; Calbet and Saiz 2005); only a few field investigations have examined whether predation effects on microzooplankton are transferred to heterotrophic nano- and picoplankton (Sipura et 
al. 2003; Zubkov and López-Urrutia 2003; Schnetzer and Caron 2005).

An ongoing issue in freshwater and marine studies is whether the obvious predatory effect of mesozooplankton on phagotrophic protists is transferred by a trophic cascade to the smallest heterotrophs, thereby indirectly regulating prokaryotic biomass, activity, and community structure. Trophic cascades are well-known to be an indirect effect of predators on plants via herbivores and have been documented for a variety of aquatic and terrestrial ecosystems (Pace et al. 1999). However, even for the plant-herbivorepredator food chain the significance of trophic cascades is variable among different habitats (Shurin et al. 2002), and biotic interactions do not always cascade within a given ecosystem. Predatory effects might be dampened because of buffering mechanisms, such as omnivory, substitutability of species, and the development of inedible prey (Strong 1992; Persson 1999).

Previous studies of cascading interactions from higher trophic levels to planktonic microorganisms were unable to provide a consistent picture of the predatory cascade. In most cases, zooplankton predation significantly affected the abundance of protist communities but did not result in significant changes in the abundance or biomass of bacterioplankton (Wickham 1998; Calbet and Landry 1999; Sipura et al. 2003). In contrast, a stronger effect on bacterial abundance is generally found when mesozooplankton consists of fine filter feeders able to directly consume picoplanktonic cells, such as the cladoceran Daphnia in limnic systems (Jürgens 1994) and appendicularians in marine systems (Sommer and Stibor 2002). Significant cascading predation effects on planktonic bacteria were also found when other parameters besides cell numbers were monitored, such as cell morphologies (Jürgens et al. 1994) or community composition (Zöllner et al. 2003). This is in accordance with recent investigations, mainly from freshwater lakes, demonstrating that prokaryotic communities rapidly adapt towards changes in predation pressure and are very heterogeneous with respect to predator vulnerability (Jürgens and Matz 2002; Šimek et al. 2002). The implication is that qualitative changes in prokaryotic communities, involving phenotypic features as well as compositional shifts, in response to predation are often more important than quantitative effects.

In the present study, large-scale marine mesocosm experiments were carried out in a North Atlantic coastal marine system in order to determine how predation by copepod-dominated mesozooplankton influences the biomass of different microbial functional groups and the composition and activity of heterotrophic bacteria. Zooplankton communities were experimentally manipulated, resulting in gradients of different population densities of copepods. Despite differences between experiments in the dominating copepod species as well as in temperature and nutrient concentrations, a similar pattern of microbial food-web structuring emerged after about 1 week of incubation. Three functionally different trophic levels within the microbial food web, i.e., ciliates, nanoflagellates, and bacteria, were found to be consistently affected by copepod grazing, with clear evidence of a predatory cascade. A strong community-wide trophic cascade was observed from copepods to ciliates and nanoplankton. Although this cascade was dampened at the level of bacterioplankton abundance, profound changes in bacterial diversity and activity nevertheless suggested that zooplankton-mediated predation effects have the potential to indirectly alter the structure and function of prokaryotic assemblages.

\section{Methods}

Mesocosm experiments-Four independent mesocosm experiments were carried out in the summer of 2001 and spring of 2002 in a sheltered, semi-enclosed marine lagoon situated at the outlet of the Trondheimsfjord, Central Norway $\left(63^{\circ} 36^{\prime} \mathrm{N}, 9^{\circ} 33^{\prime} \mathrm{E}\right)$. The hydrography of this lagoon ( $\sim 27 \mathrm{ha}, 32 \mathrm{~m}$ deep) is characterized by the daily exchange of approximately $14 \%$ of the water body because of tidal forcing (Marion 1996). The initial water temperatures, chlorophyll $a(\mathrm{Chl} a)$ concentrations, and mean start and end concentrations of inorganic nutrients are shown in Table 1. Other aspects addressed in these mesocosm experiments, such as zooplankton stable-isotope signatures and phytoplankton community analyses, were reported and summarized in an earlier study (Sommer and Sommer 2006).

To investigate the effect of copepods, which constitute the major mesozooplankton group in this system, natural plankton communities were exposed to gradients of varying copepod densities. For this purpose, transparent polyethylene enclosure bags ( $1.7 \mathrm{~m}^{3}$ volume; $1.5 \mathrm{~m}^{3}$ in summer) were filled by hauling the submerged bags to the water surface from a depth of around $3 \mathrm{~m}$. Mesozooplankton was removed by vertical net hauls with plankton nets of $250-\mu \mathrm{m}$ $(2 \times)$ and $150-\mu \mathrm{m}(10 \times)$ mesh size. Copepods were caught in a $250-\mu \mathrm{m}$ plankton net towed through the surrounding waters and transferred into a 200-liter container. To establish a pure Calanus finmarchicus gradient (experiment II), animals were collected with a net of $500-\mu$ m mesh size. Dead animals were allowed to sink to the bottom and removed before the copepods were added to the enclosures.

Each experiment consisted of copepod-free controls (Con, every $3 \mathrm{~d}$ towed with a plankton net 10 times to avoid regrowth of copepods) and four treatments with increasing nominal seeding densities of copepods (named Cop1 to Cop4), each in duplicate. The concentration of copepods (predominantly calanoids) was in the range $0-40$ individuals $\mathrm{L}^{-1}$ except in experiment II, for which the range $0-10$ individuals $\mathrm{L}^{-1}$ was chosen to account for the larger biomass of the $>500-\mu \mathrm{m}$ size fraction. The highest copepod concentration added to the mesocosms did not exceed the maxima observed in the respective system (Sommer et al. 2004). In experiments II and III (20-26 April 2002) the size structure of the copepod communities differed in that experiment II consisted of animals larger than $500 \mu \mathrm{m}$, with C. finmarchicus (mainly copepodite stages III-V) dominating the assemblage, whereas in experiment III the gradient was made up of smaller copepod species $(250-500 \mu \mathrm{m}$ in size) as well as smaller copepodite stages (CI-III) of $C$. finmarchicus. In the fourth experiment (02-08 May 2002) 


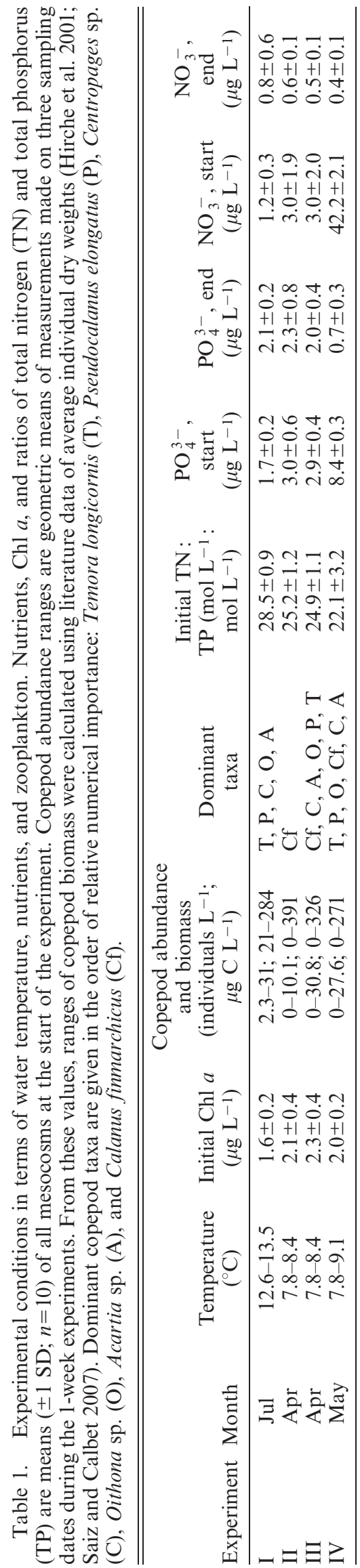

and in the summer mesocosm study (16-22 July 2001, experiment I), mixed communities of the smaller size fraction were used (for dominant species, see Table 1).

Sampling, analyses, and enumerations-After the up to $2 \mathrm{~m}$ deep mesocosms were gently mixed with a Secchi disc, samples for analysis of microbial components (picoplankton, protists) were taken daily with a 10-liter bucket. Samples for enumeration of bacteria and nanoflagellates were preserved in formaldehyde (final concentration $2 \%$ ) and stored at $4{ }^{\circ} \mathrm{C}$ until further processing (usually within the next $24 \mathrm{~h}$ ). Subsamples were filtered onto black polycarbonate filters $(25 \mathrm{~mm}$, pore size $0.2 \mu \mathrm{m}$ for picoplankton, $0.8 \mu \mathrm{m}$ for nanoflagellates), stained with $4^{\prime}, 6-$ diamidino-phenylindole (DAPI, Sigma) at a final concentration of $4 \mu \mathrm{g} \mathrm{mL}^{-1}$, and stored at $-20^{\circ} \mathrm{C}$ until enumeration by microscopy. DAPI preparations were analyzed by epifluorescence microscopy (Zeiss Axiophot) at 1250× magnification. Heterotrophic flagellates were distinguished from phototrophs based on the Chl $a$ autofluorescence of the latter following blue-light excitation. Ciliates were fixed with acid Lugol's solution (final concentration 1\%) and then counted and sized in sedimenting chambers with an inverted microscope (Zeiss Axiovert 35). After their addition, copepods were sampled twice within the week of the experiment by net hauls $(50 \mu \mathrm{m}, 12$-liter water volume), fixed with formalin (4\% final concentration), and counted under a dissecting microscope. The temporal development of bacteria and protists was analyzed for experiments I-III, whereas for experiment IV only data for the end of the experiment were obtained.

Chl $a$ was measured with a submersible fluorometer (Fluoroprobe, BBE Moldaenke) capable of registering the in vivo fluorescence of phytoplankton. Prescreened $(<100 \mu \mathrm{m})$ subsamples for measurements of inorganic dissolved nutrients, total nitrogen (TN), and total phosphorus (TP) were analyzed immediately after sampling by an autoanalyzer (Skalar SANplus) according to standard procedures (Grasshoff et al. 1999).

Determination of bacterial grazing losses-Bacterial grazing losses were estimated in a microcosm grazing experiment using fluorescently labeled bacteria (FLB; Sherr et al. 1987) and water from selected enclosures (Cop1, Cop3, Cop4) on day 5 of experiment IV. Five-hundredmilliliter Duran bottles (3 replicates + one control filtered through Whatman GF/F filter) were filled with enclosure water, which was pre-filtered (100- $\mu \mathrm{m}$ mesh size) to remove larger zooplankton. FLB were prepared according to the procedure described in Sherr et al. (1987) from a bacterial culture that had only slightly larger cell sizes (mean length $1.15 \mu \mathrm{m}$, mean cell volume $0.20 \mu \mathrm{m}^{3}$ ) than the bacterial communities in copepod mesocosms after 1 week (mean cell volume $0.18 \mu \mathrm{m}^{3}$ ). FLB were added at a final concentration of $4 \times 10^{5} \mathrm{~mL}^{-1}$ to the bottles, which were then incubated in cages in situ at a depth of around $1 \mathrm{~m}$. An incubation time of $24 \mathrm{~h}$ was sufficient to detect significant decreases in FLB concentration and to obtain a daily bacterial loss rate. Ten-milliliter subsamples, taken immediately after the addition of FLB $\left(\mathrm{t}_{0}\right)$ and after $24 \mathrm{~h}\left(\mathrm{t}_{24}\right)$, were fixed with 
formalin ( $2 \%$ final concentration), filtered onto $0.2-\mu \mathrm{m}$ polycarbonate filters, stained with DAPI, and stored at $-20^{\circ} \mathrm{C}$ until enumeration. At least $500 \mathrm{FLB}$ were counted per sample under blue-light excitation.

FLB grazing losses (after $24 \mathrm{~h}, \mathrm{t}_{0}-\mathrm{t}_{24}$ ) for each selected community, expressed as cell loss with respect to the initial FLB concentration $\mathrm{N}_{\mathrm{t}_{0}}$ (means), were calculated according to

$$
\% \text { of } \overline{\mathrm{N}}_{\mathrm{t}_{0}}=\frac{\left(\overline{\mathrm{N}}_{\mathrm{t}_{0}}-\overline{\mathrm{N}}_{\mathrm{t}_{24}}\right)-\left(\overline{\mathrm{F}}_{\mathrm{t}_{0}}-\overline{\mathrm{F}}_{\mathrm{t}_{24}}\right)}{\overline{\mathrm{N}}_{\mathrm{t}_{0}}} \times 10
$$

Here, values of GF/F-filtered controls $\left(\mathrm{F}_{\mathrm{t}_{0}}, \mathrm{~F}_{\mathrm{t}_{24}}\right)$ without protists were subtracted from the means of the treatment bottles to correct for non-grazing losses, e.g., because of the adsorption of FLB.

Measures of bacterial activity-At the start, on day 3, and at the end of all experiments, production by heterotrophic bacterioplankton was measured as ${ }^{3} \mathrm{H}-$ thymidine incorporation into cold-TCA (trichloroacetic acid)-insoluble material, essentially following the protocol in Bell (1993). ${ }^{3} \mathrm{H}$-thymidine (specific activity 87 or $90 \mathrm{Ci}$ $\mathrm{mmol}^{-1}$, Amersham) was added at a final concentration of $20 \mathrm{nmol} \mathrm{L}-1$. All samples were incubated for $1 \mathrm{~h}$ at the in situ temperature. Formalin-killed controls were used to correct for background absorption of radioactivity. Bacterial thymidine incorporation was converted to cell production using the empirical conversion factor $2 \times 10^{18}$ cells $\mathrm{mol}^{-1}$ (Ducklow and Carlson 1992).

Bacterial exoenzymatic hydrolysis rates of the enzymes protease, $\beta$-glucosidase, and phosphatase were determined by the addition, respectively, of the fluorogenic substrate analogues leucine-methylcoumarinyl-amide, methylumbelliferyl- $\beta$-D-glucoside, and methylumbelliferyl phosphate according to Hoppe (1993). To determine the maximal velocity of hydrolysis $\left(V_{\max }\right)$, substrate was added at a concentration of $250 \mu \mathrm{mol} \mathrm{L}^{-1}$ and the samples were incubated in microtiter plates (four parallels, one boiled blank) for approximately $3 \mathrm{~h}$. Fluorescence was read at the beginning and end of the incubation period in an automatic Titertek Fluoroskan II fluorometer. The factors necessary to convert fluorescence units to units of $\mu \mathrm{mol} \mathrm{L}^{-1} \mathrm{~h}^{-1}$ ( $\mu \mathrm{mol}$ of substrate hydrolyzed per unit volume and time) were derived from standard additions (one low and one high concentration) of the fluorescing compounds amidomethylcoumarin or methylumbelliferone directly to the samples after the second measurement of fluorescence.

The proportion of high-nucleic-acid (HNA) bacteria was determined by flow cytometry of fixed samples at the termination of the experiments (1\% paraformaldehyde and $0.05 \%$ glutaraldehyde, final concentration, frozen in liquid nitrogen and stored at $-80^{\circ} \mathrm{C}$ ) following the method of Gasol et al. (1999). The samples were thawed, stained with SYTO 13 (final concentration $5 \mu \mathrm{mol} \mathrm{L}^{-1}$, diluted in dimethyl sulfoxide, Molecular Probes), and run through a FACScalibur flow cytometer (Becton Dickinson) with a laser emitting at $488 \mathrm{~nm}$. Yellow-green $0.92-\mu \mathrm{m}$ latex beads (Polysciences, calibrated with Trucount ${ }^{\mathrm{TM}}$ controls, Becton Dickinson) were used as the internal standard in all measurements. Flow cytometric data were acquired and analyzed using Cell-Quest software (Becton Dickinson).

Bacterial diversity and community composition-250-mL samples were first filtered through $3-\mu \mathrm{m}$ polycarbonate filters (Millipore), then onto $0.2-\mu \mathrm{m}$ Durapore filters (Millipore). Filters were stored in lysis buffer $\left(40 \mathrm{mmol} \mathrm{L}^{-1}\right.$ ethylenediaminetetraacetic acid, $50 \mathrm{mmol} \mathrm{L}^{-1}$ Tris- $\mathrm{HCl}$, $0.75 \mathrm{~mol} \mathrm{~L}^{-1}$ sucrose) at $-80^{\circ} \mathrm{C}$ until deoxyribonucleic acid (DNA) extraction. Extraction and quantification of nucleic acids, polymerase chain reaction (PCR) amplification of $16 \mathrm{~S}$ ribosomal ribonucleic acid (rRNA) gene fragments (primers 358f-GC and 907r), analysis of the fragments by denaturing gradient gel electrophoresis (DGGE), and sequencing of excised bands followed standard procedures (Schauer et al. 2000; Schäfer and Muyzer 2001). Spectrofluorometric DNA quantification by a Hoechst dye fluorescence assay ensured that equal amounts of template DNA (6-9 ng) and PCR product (600 ng) were used. Because of a high degree of standardization, the DGGE gels and the band positions were always reproducible. High-resolution images were saved as computer files using the software GeneSnap 4.00 (SynGene). Bands with a relative intensity of $>1 \%$ were regarded as operational taxonomic units (OTUs) and included in subsequent analyses. Richness data were obtained from the number of bands per gel lane; Shannon's diversity index $\mathrm{H}^{\prime}$ was calculated from band position and the relative contribution of each band to the total intensity of the respective lane (Schauer et al. 2000). To distinguish bacterial and nonbacterial OTUs (e.g., eukaryotic plastid DNA) in diversity analyses, DGGE bands were excised from the gels, eluted, reamplified, and sequenced. Sequencing reactions with the purified products (QIAquick PCR Purification Kit, Qiagen) were done by MWG Biotech-AG. The obtained partial (up to $550 \mathrm{bp}$ ) 16S rDNA sequences (forward and reverse) were aligned using Seqman II software (Lasergene, DNAStar). The assembled consensus sequences were then compared to available 16S rRNA sequences in the GenBank database using the NCBI BLAST program.

Because our focus was mainly on the microbial responses after 1 week along gradients of copepod abundance, the temporal development of diversity was registered only in the extreme treatments (control, highest and lowest copepod abundance) of experiments I-III (start, day 3, end).

Statistical analyses-The effects of copepods on the abundances of functional groups as well as on the activity and diversity measures were analyzed by simple regression analysis (SYSTAT software) and different regression models, whereby $y$ was the parameter under investigation at the sampling day and $x$ the time-averaged (geometric mean of start, day 3 , end after 1 week) copepod abundance.

\section{Results}

Experimental conditions - Copepod populations in the mesocosms were successfully manipulated such that well- 
established gradients of copepod abundance were maintained throughout the experiments. The starting conditions differed between the four experiments, mainly in terms of inorganic nutrient concentrations and copepod community composition (Table 1). The April experiments (II and III) were carried out under conditions of low concentrations of dissolved nutrients and the predominance of the large calanoid copepod species C. finmarchicus. Although the same copepod species were present in the two experiments, experiment II exclusively consisted of animals $>500 \mu \mathrm{m}$ and was therefore conducted with a lower range of zooplankton abundance. The Trondheimsfjord water masses used in experiment IV, carried out in May, contained markedly higher levels of dissolved nitrogen and phosphorus but similar concentrations of Chl $a$. The copepod community (250-500 $\mu \mathrm{m}$ in size, as in experiment III) consisted of $C$. finmarchicus (mainly smaller copepodite stages) and other small species (Table 1). The summer experiment (I), carried out in July, was characterized by higher water temperatures, an exhaustion of nutrients, even lower chlorophyll concentrations, and a copepod community that was also dominated by smaller species (Table 1).

In all experiments, initial values of TN to TP (TN : TP) varied slightly but displayed no significant trends along the respective copepod gradients. In the course of the experiments, nitrate and phosphate were reduced more or less similarly in all enclosure bags, resulting in nutrientdepleted conditions such that final nutrient concentrations were near the detection limit (Table 1). The phytoplankton assemblages mostly consisted of diatoms, with Skeletonema costatum and Pseudonitzschia sp. as the dominant species in spring and Guinardia delicatula in summer. Moreover, the initial summer conditions deviated from those in spring by the higher numbers of nano-sized algae and a smaller proportion of dinoflagellates (Sommer et al. 2004). At the end of all experiments, clear shifts in phytoplankton size distribution became apparent, with decreases in larger forms and increases in smaller ones (Sommer and Sommer 2006).

Response in functional microbial groups-An example of the temporal development of the different functional microbial groups is given in Fig. 1, which shows the dynamics in mesocosms with maximal (Cop4) and minimal (Cop1) copepod numbers as well as in the controls (Con) without added zooplankton. These time courses already demonstrate the uniform trend in the responses of all microbial components after 1 week of incubation. Total ciliate numbers (Fig. 1A-C) substantially increased in mesocosms without copepods and in those with the lowest copepod densities until day 3 and then either remained at a high level (25-40 cells $\mathrm{mL}^{-1}$ ) throughout the experiment or slightly dropped. In contrast, ciliates clearly declined in mesocosms with high copepod abundances (Cop4), showing order-of-magnitude reductions to less than 0.2 cells $\mathrm{mL}^{-1}$.

Heterotrophic nanoflagellates (Fig. 1D-F), mostly consisting of forms $<5 \mu \mathrm{m}(>88 \%)$, increased over the course of all experiments in treatments with high copepod numbers (Cop4), but decreased in the control and in mesocosms with the lowest copepod numbers to $<1 \times$ $10^{3}$ cells $\mathrm{mL}^{-1}$ in spring (e.g., Fig. 1E) or remained at a low level in summer (Fig. 1D). Bacterial abundances (Fig. 1G-I) displayed a generally lower response amplitude over time than protists. At low copepod densities, bacterial concentrations $\left(0.52-0.87 \times 10^{6}\right.$ cells $\left.\mathrm{mL}^{-1}\right)$ slightly dropped in experiments II and III (Fig. 1G,H) or stayed the same (experiment I, Fig. 1G) until day 3, but thereafter increased in all experiments. At high copepod densities, concentrations mostly declined, either immediately (Fig. 1I) or after an initial increase (Fig. 1G,H). Here, as for the low copepod abundance mesocosms, bacterial numbers were generally higher in the summer study (experiment I), with up to $6.04 \times 10^{6}$ cells $\mathrm{mL}^{-1}$ (Con).

Because from day 3 to the end ciliate concentrations remained almost constant and lower trophic levels were expected to be successively followed by directed responses in abundance, a time point after about 1 week (day 6-day 7) was considered appropriate to compare the predationmediated effects of copepods in the various experiments. The final in-depth analysis of microbial food-web structure and activity along the complete copepod abundance gradient was therefore carried out at this sampling endpoint, although the mesocosm experiments were continued for other purposes. Analyses of the abundance data obtained after 1 week yielded an essentially uniform pattern regarding the reaction of the selected microbial trophic levels in all four mesocosm studies. The overall effect from lowest to highest copepod densities was always negative for ciliates, positive for heterotrophic nanoflagellates (HNF), and again negative for bacterioplankton (Fig. 2).

In spring, the initial ciliate community consisted mainly of cells $<40 \mu \mathrm{m}$ and a high proportion of ciliates $<20 \mu \mathrm{m}$ (around 50\%). Apart from the presence of mostly oligotrich species such as Strombidium spp., Lohmanniella sp., Leegaardiella sp., and Laboea sp., Myrionecta rubra was the predominant non-oligotrich ciliate. The summer ciliate community consisted mainly of small oligotrich species $(>80 \%)$ like Strombidium dalum. All ciliate size classes were strongly diminished by copepods (Fig. 2A-D) although this was most pronounced for the larger cells $(>20 \mu \mathrm{m})$. Ciliates drastically decreased in abundance with increasing copepod abundance and were nearly eliminated $\left(<0.1\right.$ cells $\left.\mathrm{mL}^{-1}\right)$ in mesocosms with maximal zooplankton densities.

The applied regression models and observed numerical ranges showed that increasing densities of copepods always most clearly impinged on ciliates, decreasing their abundance by up to three orders of magnitude (e.g., experiment II). In contrast, heterotrophic as well as autotrophic flagellated protists in the nanoplankton size fraction significantly increased with increasing copepod abundance (Fig. 2E-H) and reached remarkably high densities of $6000-22,000$ cells $\mathrm{mL}^{-1}$, corresponding to abundances that were between 3- and 57-fold higher for the highest vs. the lowest copepod densities. Planktonic bacteria were negatively affected at higher copepod abundances, although the response was more muted (Fig. 2I-L). In experiments II and III, highest values of $2.12-2.30 \times 10^{6}$ cells $\mathrm{mL}^{-1}$ were detected at low copepod densities but values declined to 
$\operatorname{Exp} \mathrm{I}$
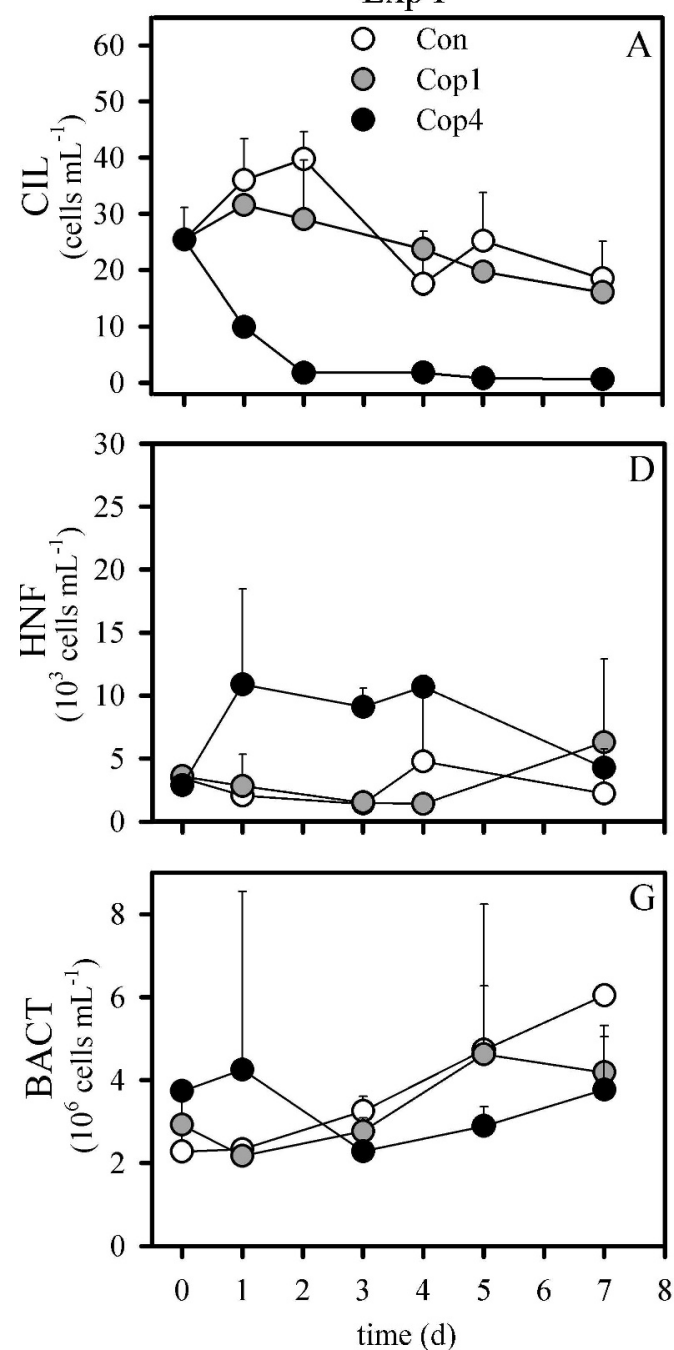

$\operatorname{Exp}$ II
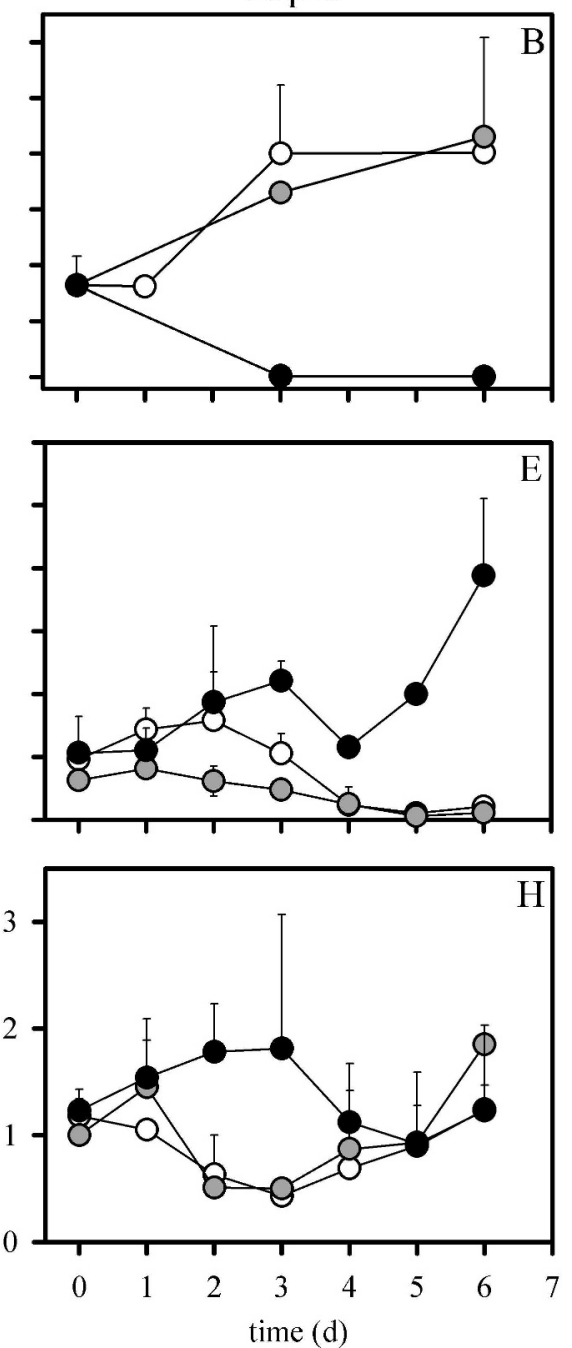

Exp III
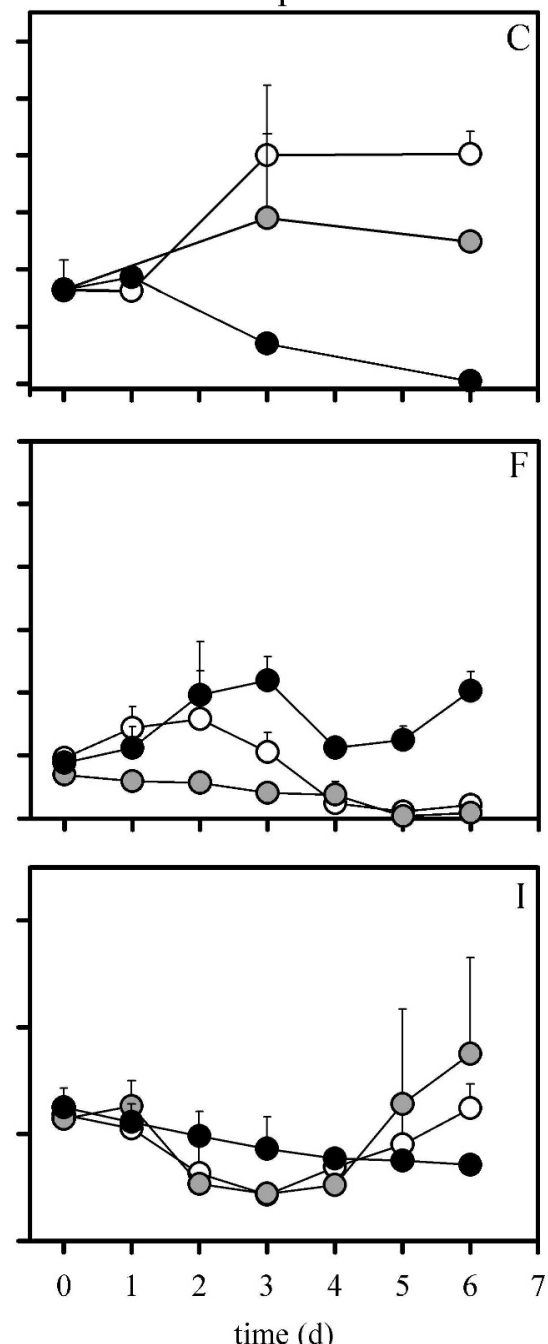

Fig. 1. Time course of (A-C) ciliate (CIL), (D-F) heterotrophic nanoflagellate (HNF), and (G-I) bacterial (BACT) abundances in three different experiments (I, II, III). Selected mesocosms are bags either without mesozooplankton (Con) or with lowest (Cop1) and highest (Cop4) copepod densities, respectively. Error bars show the range between replicate mesocosms.

around $1 \times 10^{6}$ cells $\mathrm{mL}^{-1}$ as copepod numbers increased. Experiments I and IV largely showed the same trends but absolute bacterial concentration ranges were higher in the former $\left(2.36-6.16 \times 10^{6}\right.$ cells $\left.\mathrm{mL}^{-1}\right)$ and lower in the latter $\left(0.44-1.32 \times 10^{6}\right.$ cells $\left.\mathrm{mL}^{-1}\right)$.

Predator-prey ratios-Because of the significant alterations in abundance over time and along copepod gradients, as described above, the predator-prey ratios between adjacent trophic levels drastically shifted. Pooled data from all four experiments indicated that the proportion of HNF to ciliates increased by nearly five orders of magnitude along the copepod gradient (Fig. 3A). The average ratios corresponded to $250 \times 10^{3} \mathrm{HNF}$ per ciliate in the highest and $0.13 \times 10^{3} \mathrm{HNF}$ per ciliate in the lowest copepod abundance treatments. The bacteria: HNF ratio, in turn, significantly decreased by more than two orders of magnitude with increasing copepod densities (Fig. 3B), commensurate with 2359 bacteria per HNF in the lowest and 172 bacteria per HNF in the highest copepod abundance enclosures. This reduced amplitude, compared to the HNF : ciliate ratio, mainly resulted from the fact that bacterial abundances changed to a much lesser extent than the abundances of protist communities (Figs. 1, 2).

Bacterial grazing losses-In order to compare bacterial grazing losses between mesocosms with contrasting protist communities (ciliates vs. HNF), an FLB disappearance experiment using water from mesocosms with different zooplankton densities (only experiment IV) was performed. Protist grazing pressure on bacterioplankton, expressed as relative FLB removal, markedly changed according to the prevailing copepod regime, i.e., it was distinctly enhanced in higher vs. lower copepod abundance treatments (Fig. 4). Thereby, much stronger grazing losses occurred in mesocosms with higher copepod numbers, containing higher HNF and lower ciliate abundances (e.g., Cop3, Cop4), compared to mesocosms with higher ciliate but lower HNF 

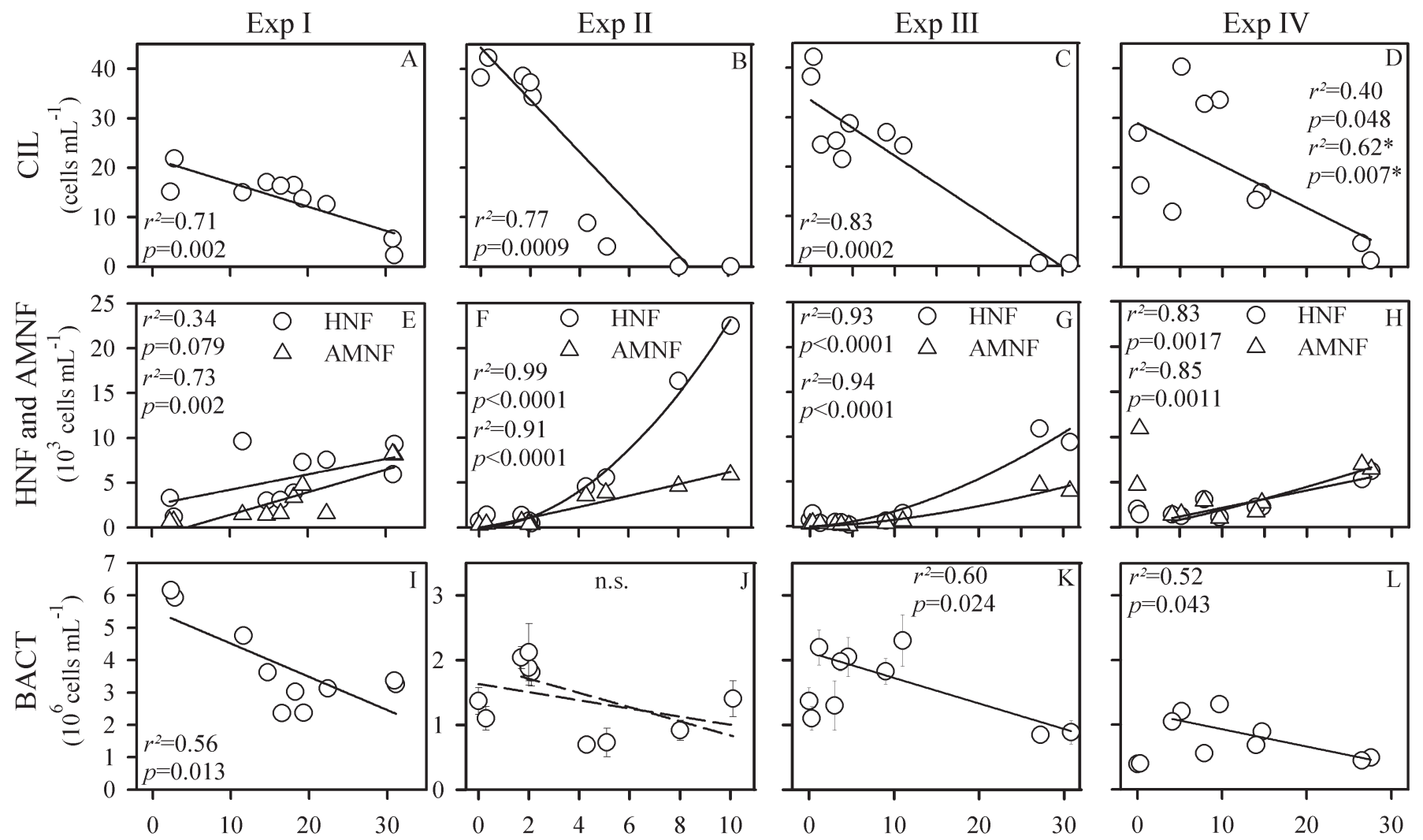

Copepods $\mathrm{L}^{-1}$

Fig. 2. Cascading copepod predation effect on the lower food web. Abundances of (A-D) ciliates (CIL), (E-H) heterotrophic (HNF) as well as autotrophic and mixotrophic (AMNF) nanoflagellates, and (I-L) heterotrophic bacteria (BACT) along the respective copepod gradients (geometric means) in experiments I-IV after 1 week. Solid regression lines indicate significance. In $\mathrm{H}$ and $\mathrm{J}-\mathrm{L}$, Con mesocosms were not included in regression. * Regression with log-transformed data.

abundances (Cop1). Based on the FLB disappearance rates, daily bacterial grazing losses were estimated to be 9 $23 \%$ at $\mathrm{HNF}$ concentrations below $1600 \mathrm{~mL}^{-1}$ (low copepod abundance treatments Cop1), and $41-54 \%$ of the bacterial standing stock in mesocosms with higher HNF numbers $\left(>6000 \mathrm{~mL}^{-1}\right)$.

Effect on bacterial community parameters: Abundance, activity and diversity - Although in all experiments a clear negative effect on bacterial densities was detected at high copepod abundances (Fig. 2), bacterial cell numbers were variable. However, the pooled data set from experiments II-IV (spring experiments) showed a significant reduction with increasing copepod abundance (Fig. 5A). Because of the generally higher bacterioplankton concentrations in experiment I (summer), the significant drop took place at a higher level of bacterial abundance and is thus not included in the regression function shown in Fig. 5A.

Overall, bacterial production strongly decreased with higher copepod densities (Fig. 5B). This was paralleled by a clear reduction in the ratio of HNA bacteria to bacteria with low nucleic acid content as a function of copepods (Fig. 5B) and thus also of HNF abundance (log function, $R^{2}=0.66, p<0.0001$, not shown in graph). The decline in bacterial production was even more pronounced than the decreases in abundance (Fig. 2; Table 2), indicating substantial effects also at the level of cell-specific bacterial activity. When cell-specific carbon production of bacterioplankton was calculated, a negative relationship similar to that found for total production was determined, corresponding to reductions of up to $60 \%$ between the lowest and the highest copepod densities (data not shown).

The drop in the activities of the three investigated bacterial exoenzymes with increasing copepod densities was comparable to the decrease in overall production (Fig. 5C). However, the response amplitudes across the gradient diverged between the different enzymes and were most pronounced for $\beta$-glucosidase (Table 2). For this enzyme, absolute activity and cell-specific hydrolysis rates decreased significantly across the copepod gradient (plot analogous to Fig. 5C, data not shown, power regression $R^{2}=0.60, p=$ 0.0002 ), with reductions between the lowest and highest copepod abundance of up to $60 \%$. With respect to cellspecific rates, the other two enzymes, protease and phosphatase, were less affected and significantly decreased in only two out of three experiments (data not shown).

Interestingly, the parameters characterizing bacterial community composition showed striking directional changes in response to manipulations of copepod densities. Both Shannon's diversity index $\mathrm{H}^{\prime}$ (Fig. 5D; Table 2) and the 


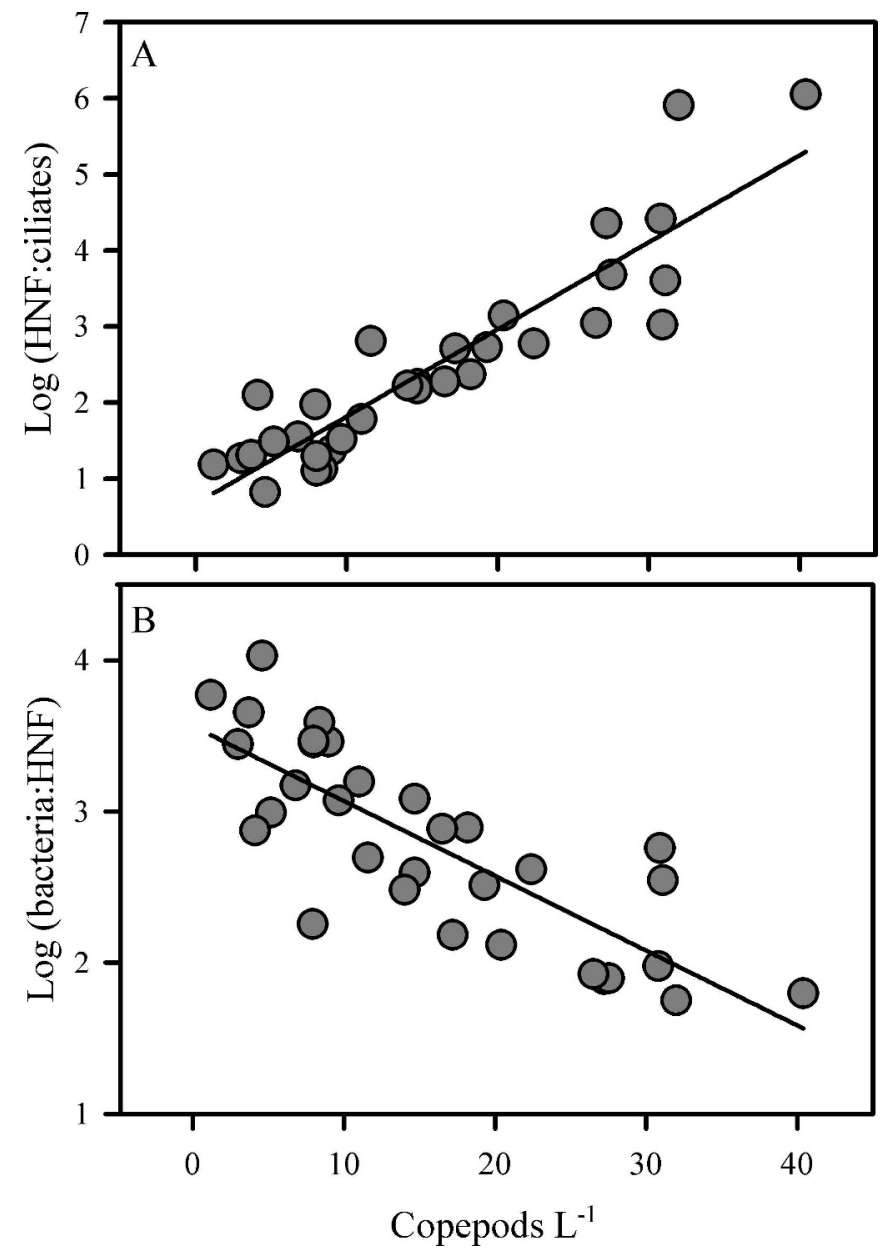

Fig. 3. Response of microbial food-web structure to increasing copepod abundance. Logarithmic ratios of abundances of adjacent functional groups within the copepod-mediated trophic cascade are shown: (A) the ratio of heterotrophic nanoflagellates (HNF) to ciliates and (B) the ratio of bacteria to HNF. In order to standardize the scales, four times the densities of the large $C$. finmarchicus were taken, as the biomass of this species was assumed to be approximately four times higher than that of the other copepods. To account for time-integrated grazing effects, copepod densities are given as the geometric means of three sampling dates. Each data point stands for one independent mesocosm after 1 week of experimental duration. The significant regression function for (A) is $\mathrm{y}=0.67+0.11 \mathrm{x}, R^{2}=0.83, p<$ 0.0001 ; for $(\mathrm{B}), \mathrm{y}=3.56-0.05 \mathrm{x}, R^{2}=0.65, p<0.0001$.

overall OTU richness (number of DGGE bands; see Table 2) significantly increased as a function of copepod abundance. Sequence information from the excised DGGE bands revealed that a number of eukaryotic chloroplasts were amplified as well. Therefore, the diversity analysis could be differentiated for bacterial OTUs alone or for all DGGE bands, including eukaryotic plastid-derived bands. However, the general trend of asymptotically increasing Shannon diversity with increasing copepod abundance was similar for both calculations (Fig. 5D). These notable shifts in the patterns of bacterial diversity resulted from changes in relative band intensities and from total band numbers and positions. The appearance of up to four new bacterial

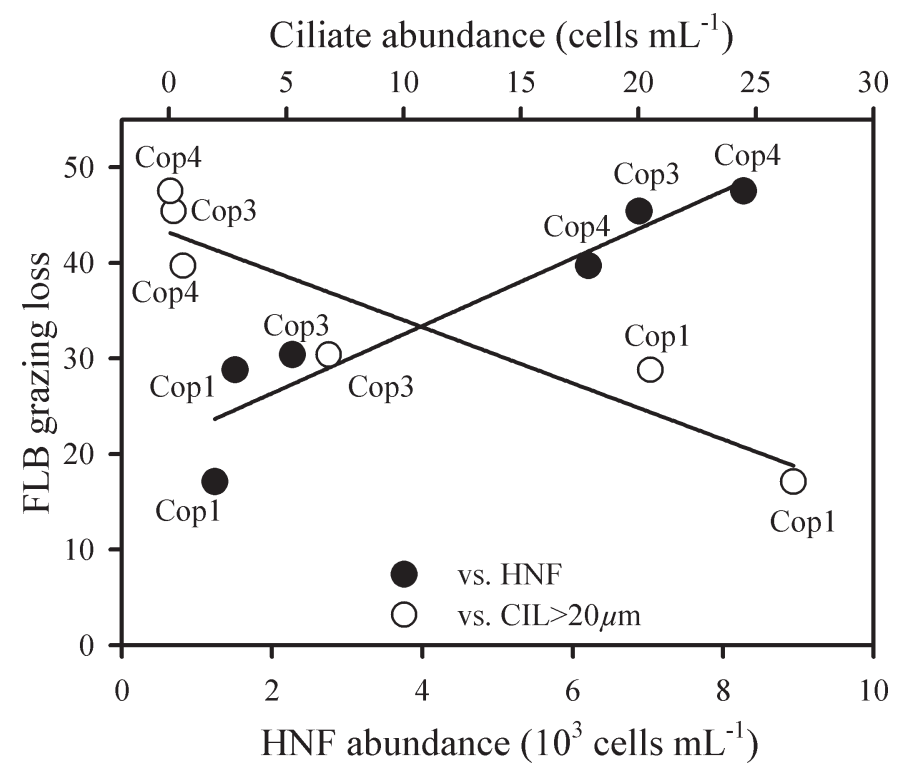

Fig. 4. Differential effect of HNF and ciliates $(>20 \mu \mathrm{m}$; initial abundances) on the percentage of fluorescently labeled bacteria (FLB) grazing loss (percentage of initial FLB concentration, arcsin-transformed data) in selected mesocosms with low (Cop1) and high (Cop3, Cop4) copepod densities. Two mesocosms per copepod abundance treatment were investigated, each with 3 replicate bottles. Coefficients of variation of FLB loss between these 3 replicates are: $\mathrm{T}_{0}$ : Cop $1=0.099$ and 0.028 , Cop3 $=0.109$ and 0.084, Cop4 $=0.057$ and 0.016; $\mathrm{T}_{24}$ : Cop1 $=0.019$ and 0.144 , Cop3 $=0.075$ and 0.236 , Cop $4=0.124$ and 0.314 . Regressions significant at $p<0.05$.

OTUs at higher copepod densities led to a highly significant positive relationship between microbial OTU richness and copepod abundance (power regression for all OTUs, $R^{2}=$ $0.61, p<0.0001$; for bacterial OTUs only, $R^{2}=0.35, p=$ 0.0022 , data not shown in graph).

The overall effects on bacterioplankton displayed a clear pattern that can be summarized as follows: Increasing copepod abundance, concomitant with lower ciliate numbers and increasing heterotrophic nanoflagellate predation on bacteria, resulted in slight negative effects on total bacterial abundance, stronger negative effects on bacterial activity and production, and an increase of bacterial diversity and richness.

\section{Discussion}

Copepod-mediated trophic cascade-Despite the initial differences between the experiments in terms of abiotic conditions and biotic components, similar effects of copepods on the different functional microbial groups were observed. The alternating responses of ciliates, HNF, and bacteria along zooplankton gradients, as described in this study, likely resulted from short-term predation effects that started at the level of copepods and propagated down through three adjacent trophic levels, made up of functional groups of heterotrophic microorganisms. As indicated by the numerical ratios between lowest and highest copepod treatments, the strongest response oc- 

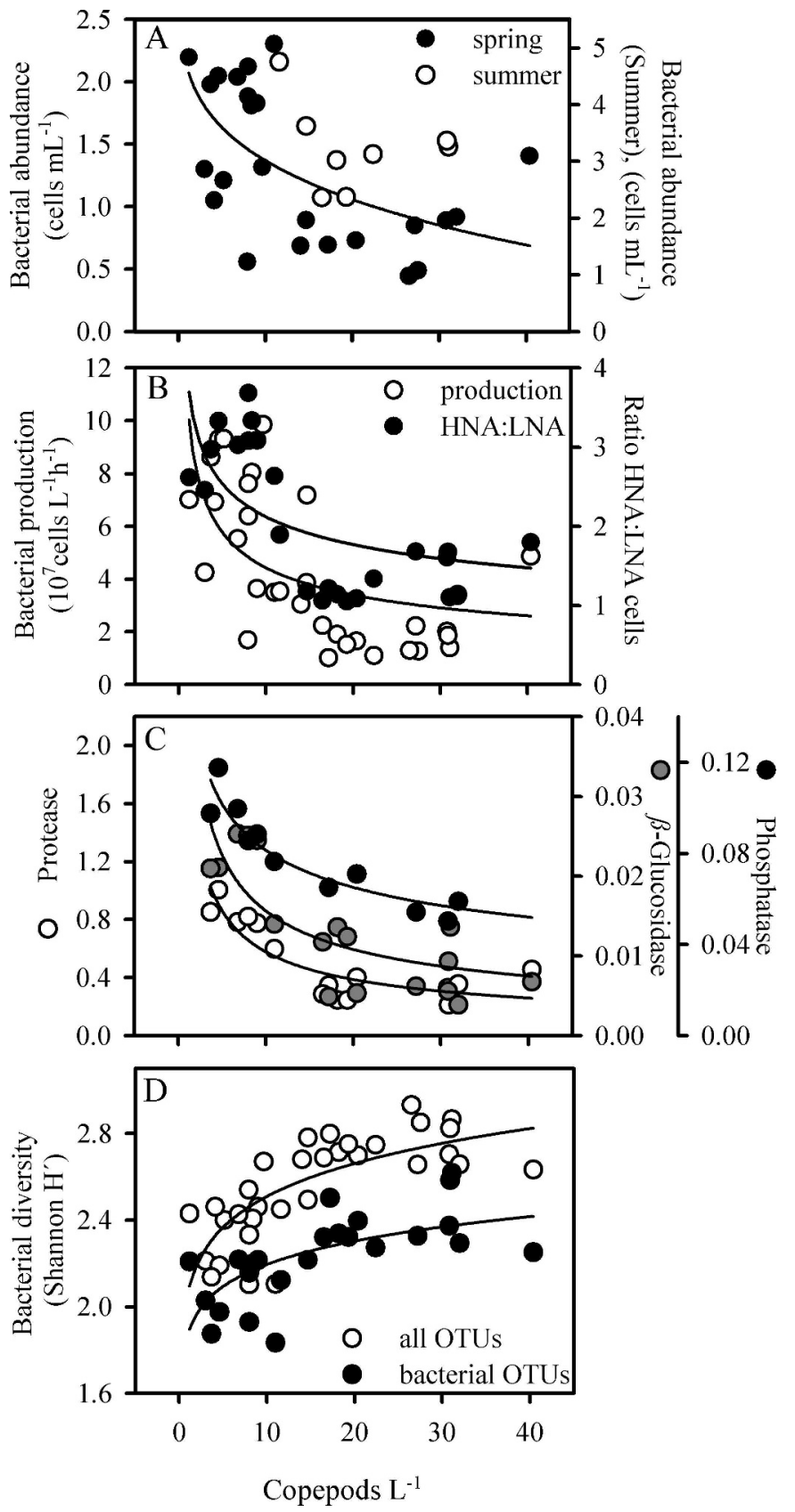

Fig. 5. Copepod effects on bacterioplankton abundance, activity, and diversity. Several parameters demonstrate the community response of bacteria as a function of copepod abundance (as geometric mean of three sampling dates). Data from spring and summer experiments I-IV were pooled. Each data point stands for one independent mesocosm after 1 week of experimental duration. (A) Bacterial abundance; (B) bacterial production and ratio of high nucleic acid (HNA) to low nucleic acid (LNA) bacteria; (C) exoenzyme activity (maximal velocity of hydrolysis $V_{\max }$ in $\left.\left[\mu \mathrm{mol} \mathrm{L} \mathrm{L}^{-1} \mathrm{~h}^{-1}\right]\right)$; (D) Shannon's index $\mathrm{H}^{\prime}$ of bacterial and all OTU (operational taxonomic unit) diversity. Regression function in (A), $\mathrm{y}=3,200,803-1,084,361 \mathrm{x}^{0.23}, R^{2}=$ $0.35, p<0.05$ (spring experiments II, III, IV). All power functions in (B)-(D) are significant at $p<0.001$. Equations in (B) are $\mathrm{y}=$ $17.74 \mathrm{x}^{-0.38}, R^{2}=0.37$ (cell production) and $\mathrm{y}=3.87 \mathrm{x}^{-0.26}, R^{2}=$ 0.40 (experiments I, II, III); in (C), y $=0.17 \mathrm{x}^{-0.32}, R^{2}=0.87$ (phosphatase, experiments II, III), $\mathrm{y}=0.05 \mathrm{x}^{-0.54}, R^{2}=0.63 \mathrm{x}$ curred at the level of ciliates, the most dampened and complex one at the level of bacteria (Fig. 6). This interpretation of the patterns displayed in the mesocosms is consistent with information derived from numerous experimental and observational studies, in limnic and in marine plankton communities, regarding predator-prey interactions between copepods and ciliates, ciliates and nanoplankton, and nanoflagellates and bacteria.

Although copepods have traditionally been regarded as herbivores, they are generally omnivorous and have evolved mechanosensory systems to detect and efficiently capture motile prey, such as ciliates (Kiørboe 1997), which are often preferentially consumed compared to phytoplankton. Furthermore, it has been demonstrated in various systems that copepod predation can control the number of planktonic ciliates (Kiørboe 1997; Calbet and Saiz 2005). Although not all ciliate taxa and size classes are equally vulnerable to copepod predation, and some selective predation consequences for ciliate communities have been found (Broglio et al. 2004; Wickham and Berninger 2007), the majority of medium to larger size classes of ciliates, particularly the oligotrichs that generally dominate in planktonic systems, are often strongly grazed (Perez et al. 1997; Levinsen et al. 2000). The trophic link between copepods and microzooplankton, including not only ciliates but also dinoflagellates as another important group, is assumed to be quantitatively relevant for overall marine pelagic carbon fluxes (Calbet and Saiz 2005).

The strong linkage between ciliates and HNF within the observed trophic cascade is supported by experimental laboratory studies showing that oligotrichous ciliates are highly efficient feeders on nanoplanktonic prey (Kivi and Setälä 1995). Accordingly, ciliates have the potential to serve as a link between the classical and the microbial food web. The linkages of the copepod-ciliate-nanoflagellate food chain were recognized some time ago (Sheldon et al. 1986) but could not always be verified in field experiments. Experimental incubations with copepod zooplankton nearly always resulted in decreases of ciliate numbers, which in turn should have positively affected nanoplankton because of relief from ciliate grazing. This was indeed observed in several studies for autotrophic (Stibor et al. 2004) and heterotrophic (Calbet and Landry 1999; Schnetzer and Caron 2005) nanoplankton. However, there are also case studies in which no net effect of diminished ciliate abundance on nanoplankton was observed (Sipura et al. 2003; Wickham and Berninger 2007). Possible underlying reasons for a lack of a trophic cascade response are a more complex microbial food web with additional predatory groups (e.g. larger flagellates) or strong resource control, which in turn prevents the growth of lower trophic levels after predation relief.

( $\beta$-glucosidase, experiments I, II, IV) and $\mathrm{y}=2.20 \mathrm{x}^{-0.58}, R^{2}=$ 0.79 (protease, experiments I, II, III); in (D), y $=1.87 \mathrm{x}^{0.07}, R^{2}=$ 0.41 (bacterial OTUs, experiments I, II, III) and y $=2.06 \mathrm{x}^{0.09}, R^{2}$ $=0.53$ (all OTUs, experiments I-IV). 
Table 2. Copepod effects on bacterial diversity and activity. Activity measures are cell production (calculated from ${ }^{3} \mathrm{H}$-thymidine uptake) and maximal velocity of polymer hydrolysis $\left(V_{\max }\right)$ for three selected enzymes. OTU, operational taxonomic unit; OE, overall positive $(+)$ or negative $(-)$ effect on respective parameter; PR, parameter range along the copepod gradient; RM, regression model ( $1=$ linear; $2=$ power or logarithmic); n.s., not significant if $p>0.05$; n.d. not determined. Regression statistics are given by values of $R^{2}$ and $p$. In experiments II-IV, Con mesocosms were not included in regressions.

\begin{tabular}{|c|c|c|c|c|c|c|}
\hline Experiment & $\begin{array}{l}\text { Total } \\
\text { OTU } \\
\text { richness }\end{array}$ & $\begin{array}{c}\text { Total } \\
\text { Shannon } \\
\text { diversity } \mathrm{H}^{\prime}\end{array}$ & $\begin{array}{c}\text { Bacterial } \\
\text { production } \\
\left(10^{7} \text { cells } \mathrm{L}^{-1} \mathrm{~h}^{-1}\right)\end{array}$ & $\begin{array}{c}\text { Protease } \\
V_{\max } \\
\left(\mu \mathrm{mol} \mathrm{L}-1 \mathrm{~h}^{-1}\right)\end{array}$ & $\begin{array}{c}\beta \text {-glucosidase } \\
V_{\max } \\
\left(\mu \mathrm{mol} \mathrm{L}-1 \mathrm{~h}^{-1}\right)\end{array}$ & $\begin{array}{c}\text { Phosphatase } \\
V_{\max } \\
\left(\mu \mathrm{mol} \mathrm{L}-1 \mathrm{~h}^{-1}\right)\end{array}$ \\
\hline $\mathrm{OE}$ & + & + & - & - & - & - \\
\hline PR & $18-21$ & $2.45-2.87$ & $7.18-1.10$ & $0.286-0.210$ & $0.014-0.009$ & $0.143-0.123$ \\
\hline $\mathrm{RM}$ & 1 & 1 & 1 & 1 & 1 & 1 \\
\hline \multicolumn{7}{|l|}{ II } \\
\hline $\mathrm{OE}$ & + & + & - & - & - & - \\
\hline PR & $12-20$ & $2.10-2.80$ & $8.04-1.01$ & $0.819-0.356$ & $0.025-0.004$ & $0.100-0.059$ \\
\hline $\mathrm{RM}$ & 2 & 2 & 2 & 2 & 2 & 1 \\
\hline$p$ & 0.001 & 0.041 & 0.113 (n.s.) & 0.038 & 0.005 & 0.043 \\
\hline$R^{2}$ & 0.67 & 0.53 & 0.37 & 0.70 & 0.89 & 0.79 \\
\hline$p$ & 0.0002 & 0.023 & 0.034 & 0.004 & 0.009 & 0.007 \\
\hline$R^{2}$ & 0.91 & 0.60 & 0.53 & 0.90 & 0.85 & 0.86 \\
\hline \multicolumn{7}{|l|}{ IV } \\
\hline $\mathrm{OE}$ & + & + & - & n.d. & n.d. & n.d. \\
\hline PR & $15-23$ & $2.40-2.93$ & $9.84-1.27$ & & & \\
\hline $\mathrm{RM}$ & 1 & 1 & 1 & & & \\
\hline$p$ & 0.002 & 0.001 & 0.055 & & & \\
\hline$R^{2}$ & 0.82 & 0.84 & 0.48 & & & \\
\hline
\end{tabular}

HNF, as the major grazers of planktonic bacteria, would be expected to propagate this heterotrophic predatory cascade to the level of bacterioplankton. However, although reductions in bacterial concentrations along the copepod gradient were observed (Fig. 2), the effect was clearly muted compared to the strong responses in microand nanoplankton, and only significant for the spring experiments (Fig. 5A). This finding is in accordance with other experimental studies in marine (Calbet and Landry 1999) and freshwater (Wickham 1998) plankton as well as in terrestrial detritus food webs (Mikola and Setälä 1998), which did not find strong cascading effects on bacterial abundance after changes in higher trophic levels and in the abundance of bacterivores. It is also in line with studies on the fish-zooplankton-phytoplankton food chain, mainly in lakes, which showed that food-web effects become increasingly dampened as they pass to lower trophic levels (McQueen et al. 1989). However, for bacteria, other compensatory mechanisms that prevent predatory cascades from affecting bacterial abundance might be relevant (see below).

Our findings on the effects of the copepod-mediated trophic cascade on purely heterotrophic microorganisms are consistent with the observed results of size-selective copepod predation on autotrophic plankton, in which the copepod-ciliate linkage also seems to be decisive for food- web structuring: large-sized phytoplankton (e.g., diatoms) become reduced by direct grazing, whereas nano-sized algae are positively correlated to copepods because of topdown control of ciliates (Stibor et al. 2004; Sommer and Sommer 2006). Copepod predation on ciliates even resulted in a stimulation of picocyanobacteria (Sundt-Hansen et al. 2006), which is in contrast to our observed effects on heterotrophic bacterioplankton. It suggests that, at the level of picoplankton, where autotrophs such as Synechococcus are generally slightly larger than heterotrophic bacteria, prokaryotic cell sizes determine whether HNF or ciliates are the major grazers and thereby how the cascading zooplankton predation effects will function.

Cascading predation effects on the structure and function of bacterial assemblages - The inclusion of bacterial diversity and activity as bacterial response parameters revealed the remarkable qualitative and quantitative changes that occurred within the bacterioplankton assemblages (Table 2), thus shedding new light on the complexity within this trophic level. As the most striking outcome of this study, copepods were found to exert distinct cascading effects on bacterioplankton community composition, production, and hydrolytic potential. Although the underlying mechanisms for the consistent shifts in bacterioplankton activity and composition remain to be established, preda- 


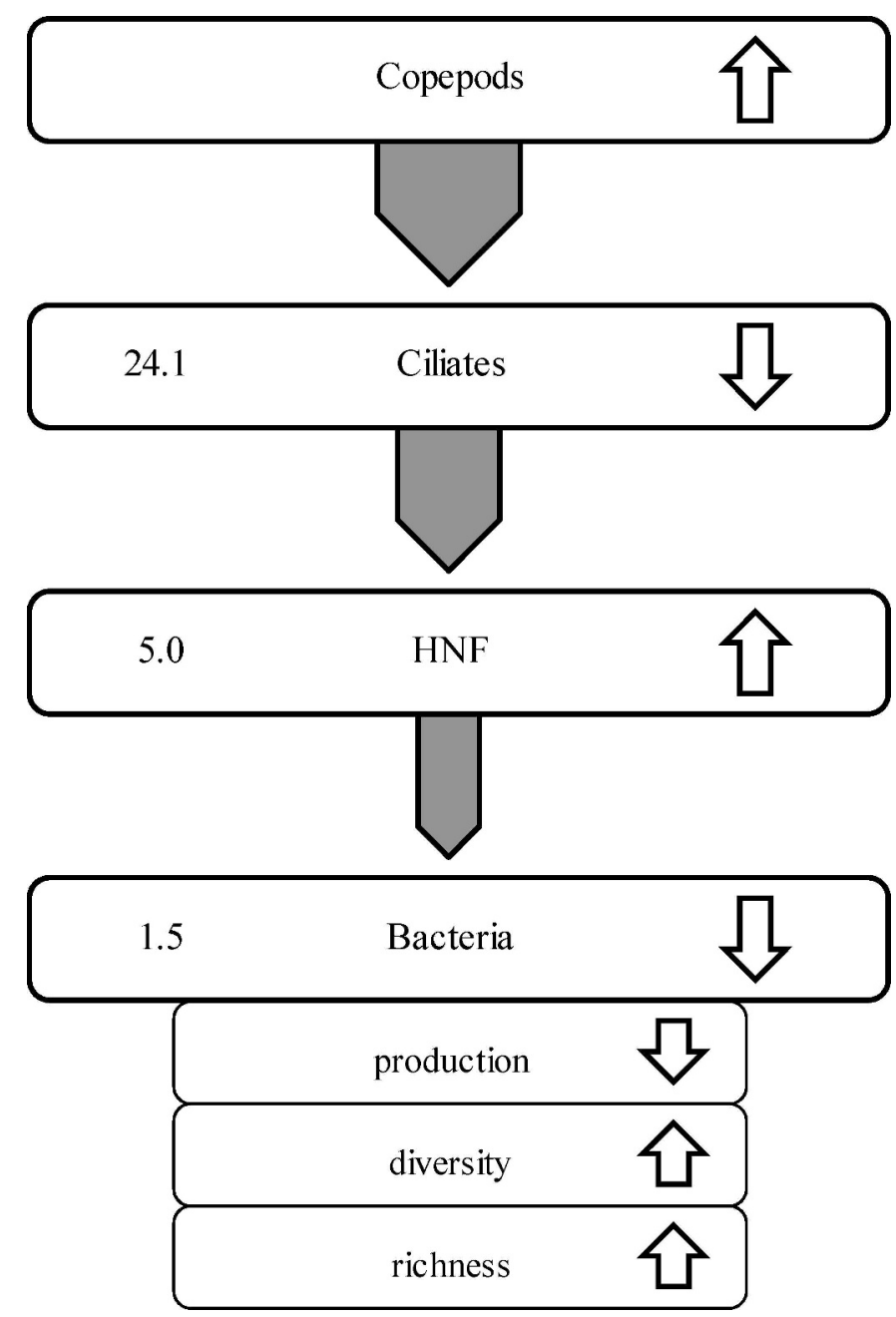

Fig. 6. Conceptual scheme of the copepod-mediated trophic cascade as observed in the mesocosm experiments. Trophiccascade dampening and the differential effect on bacteria are demonstrated. Arrows (right) indicate positive or negative responses of the respective functional groups or parameters. Numbers on the left are ratios derived from dividing abundance values measured in the two lowest (averaged data from all four experiments, $n=8$ ) and two highest (averaged data from all four experiments, $n=8$ ) copepod abundance mesocosms at the end of the different experiments.

tion effects by HNF were most likely the dominating factor. A causal mechanism for a stronger decrease in bacterial activity parameters (production, exoenzymatic activity) than in abundances (Fig. 5) might be the fact that bacterivorous nanoflagellates selectively prey on larger, more productive bacterial cells (Sherr et al. 1992), thereby changing the size structure of the community and reducing overall bacterial production (Del Giorgio et al. 1996).

Predation pressure by bacterivores can also trigger shifts in bacterial community composition by promoting the development of predation-resistant taxa (Jürgens and Matz 2002; Šimek et al. 2002). Hence, intense HNF grazing pressure at higher copepod densities resulted in a strong decline of the active bacterioplankton fraction, which might have prevented the dominance of a few opportunistic bacterial taxa and thus promoted the coexistence of numerous but less abundant phylotypes. Newly occurring bacterial OTUs and an increased diversity at higher copepod and thus HNF densities also suggest additional functional properties within the bacterial assemblage. A shift in the functional potential might also be inferred from the deviating responses in cell-specific exoenzyme activities associated with these compositional changes. The abovedescribed pattern of decreasing bacterial activity and a concomitant increase in diversity was recently also observed on a larger temporal and spatial scale in a marine system (Reinthaler et al. 2005) but without an examination of the possible trophic interactions involved.

Although there are other known mechanisms affecting the structure and activity of natural bacterial communities, such as alterations in substrate supply (Øvreås et al. 2003) and virus-induced mortality (Weinbauer and Rassoulzadegan 2004), the experimental conditions of low nutrient availability coinciding with intense grazing pressure of HNF on bacteria obviously facilitated dominance of the copepod predatory cascade in shaping microbial performance. Another indirect, stimulatory effect of mesozooplankton grazers on bacterioplankton is caused by release of organic matter when grazing on phytoplankton (Møller et al. 2003). However, in our mesocosm experiments bacterial production was negatively correlated to copepod abundance (Fig. 5B), which implies that the predatory interactions were more important than effects caused by organic substrate production.

The microbial population dynamics observed in our experiments must be seen as a transitory state reflecting the short-term responses of the different functional groups. Although a stable steady state was probably not achieved, 1 week of experimental analysis was nonetheless sufficient to allow predation effects to cascade through several generations of the microorganisms involved. On a longer timescale, either a cyclic behavior of the different predator-prey relationships or a dampening of the cascade caused by compensatory mechanisms, such as the development of predation avoidance, could be expected (Abrams 2000). However, experimental studies that include responses of bacterial communities can be of only limited duration, as secondary enclosure effects will become influential. In our experimental design, with a complete gradient of zooplankton densities, experimental mesocosms consisting of large volumes relative to the organisms under investigation, and a short incubation time, the occurrence of artificially strong perturbations was unlikely. However, in freshwater systems, long-term responses in heterotrophic microbial communities have been assessed by experiments at the ecosystem scale, e.g., whole-lake experiments (Carpenter et al. 2001), which yielded insights that were different from those obtained in the short-term incubation experiments described here.

Implications for marine pelagic food webs-Trophic cascades are likely to be widespread in nature but are best understood for classical food chains of carnivores, herbivores, and primary producers (Pace et al. 1999), whereas the responses of bacteria and other small heterotrophs, 
including their functional and compositional properties, have rarely been studied. To our knowledge, our mesocosm studies represent the first documented case of a four-link predatory cascade affecting entire functional groups of mainly heterotrophic organisms. In their strength and magnitude, the results parallel those obtained for carnivore-herbivore-plant cascades, known from a variety of systems and being particularly pronounced in aquatic ones (Strong 1992; Brett and Goldman 1996; Shurin et al. 2002). A meta-analysis of published studies revealed that strong cascading predation effects occur less often in marine than in freshwater systems (Shurin et al. 2002). However, this conclusion refers mainly to the predation cascade involving primary producers. Our study demonstrates that strong trophic cascades affecting heterotrophic microorganisms do occur in marine plankton.

The terminology and the concept of trophic cascades have been discussed in the literature, and to account for the heterogeneity within trophic levels, recent studies distinguished between "species cascades," whereby changes in predators affect only a subset of the community, and "community-level cascades," in which the biomass of whole trophic levels is changed (Polis et al. 2000). It has been argued that only the latter type are "true" trophic cascades but that they are the exception rather than the rule and found mainly in aquatic ecosystems, affecting the biomass of primary producers (Strong 1992; Chase 2000).

For the purely heterotrophic part of the food chain examined in our experiments, a clear community-wide cascade occurred, i.e., from copepods to ciliates and nanoflagellates. The underlying reasons for the observed community-level dynamics are size-structured predatorprey interactions, a rather simple linear heterotrophic food chain, the pelagic zone as a relatively homogenous habitat, and the fact that ciliates and flagellates are uniformly edible by their predators. The dampened effects at the bacterial level may have been caused by heterogeneity within the bacterial assemblages with respect to predator vulnerability (Jürgens and Matz 2002). This would promote, instead of community-wide cascades, different species-level cascades in which predation-sensitive bacterial taxa are most notably influenced. This view is supported not only by the observed changes in bacterial diversity but also by other studies, in which specific molecular probes were used to visualize the population dynamics within the bacterial assemblage. Those results revealed that some taxa strongly decrease whereas others may even increase in response to enhanced predation (Šimek et al. 2002).

Whether our results remain valid on larger spatial and temporal scales in marine plankton communities has to be verified by complementary approaches to incubation experiments, e.g., empirical analyses of in situ community and population dynamics of the different functional groups. The decisive factor determining whether cascading predation effects on lower trophic levels can be expected is probably the zooplankton biomass of the particular system. For oligotrophic open-ocean systems, the overall influence of mesozooplankton on microbial food webs was estimated to be very small because of the low zooplankton biomass (Calbet and Landry 1999). Although we observed a more or less continuous response of the assessed microbial functional groups to increasing copepod densities, strong changes in the abundance of ciliates and nanoflagellates were visible at copepod concentrations in the range of 4-15 individuals $\mathrm{L}^{-1}$. Similarly high copepod concentrations are found in coastal marine plankton (Kiørboe 1997) and in phytoplankton patches (Henjes et al. 2007). In these cases, predatory cascades on microbial food webs, comparable to those present in our mesocosm experiments, are to be expected. More data are needed to verify whether global patterns in the distribution of microbial communities and associated properties in the ocean are related to changes in food-web interactions, as some analyses have suggested (Rivkin and Legendre 2002).

Our findings also raise a novel aspect in the current debate regarding how changes in species abundance and diversity influence the structure and functioning of ecosystems (Loreau et al. 2001). The composition and activity of bacterial assemblages not only are a reflection of the actual substrate supply but also are mediated by strong food-web interactions. The diversity and physiological potentials that play important roles at the bacterial level are those that most strongly affect ecosystem processes, such as nutrient uptake and mineralization rates, element and energy transfer, community respiration, and the decomposition of organic matter. Therefore, changes in the biomass and composition of higher trophic levels can indirectly influence microbially mediated ecosystem processes by predation effects that propagate from metazoans to the lowest trophic levels of heterotrophic plankton organisms. In the case of plankton, different guilds of mesozooplankton are responsible for different trophic cascades. For example, when appendicularians or cladocerans instead of copepods dominated, different effects on the lower-food-web structure were induced (Sommer and Stibor 2002; Zöllner et al. 2003; Sommer and Sommer 2006). Because zooplankton communities themselves are strongly influenced by higher trophic levels, such as planktivorous fish (Verity and Smetacek 1996; Pauly et al. 1998) or ctenophores (Granéli and Turner 2002), it is possible that the range of cascading interactions extends even further, e.g., from fish to bacteria, in marine planktonic food chains.

\section{References}

Abrams, P. A. 2000. The evolution of predator-prey interactions: Theory and evidence. Annu. Rev. Ecol. Syst. 31: 79-105.

Bell, R. T. 1993. Estimating production of heterotrophic bacterioplankton via incorporation of tritiated thymidine, p. 495-503. In P. F. Kemp, B. F. Sherr, E. B. Sherr and J. J. Cole [eds.], Handbook of methods in aquatic microbial ecology. Lewis Publishers.

Brett, M. T., AND C. R. Goldman. 1996. A meta-analysis of the freshwater trophic cascade. Proc. Natl. Acad. Sci. USA 93: $7723-7726$.

Broglio, E., E. Saiz, A. Calbet, I. Trepat, and M. Alcaraz. 2004. Trophic impact and prey selection by crustacean zooplankton on the microbial communities of an oligotrophic coastal area (NW Mediterranean Sea). Aquat. Microb. Ecol. 35: $65-78$. 
Calbet, A., And M. R. Landry. 1999. Mesozooplankton influences on the microbial food web: Direct and indirect trophic interactions in the oligotrophic open ocean. Limnol. Oceanogr. 44: 1370-1380.

—, AND E. SAIZ. 2005. The ciliate-copepod link in marine ecosystems. Aquat. Microb. Ecol. 38: 157-167.

CARPenter, S. R., AND others. 2001. Trophic cascades, nutrients and lake productivity: Experimental enrichment of lakes with contrasting food webs. Ecol. Monogr. 71: 163-186.

Chase, J. M. 2000. Are there real differences among aquatic and terrestrial food webs? Trends Ecol. Evol. 15: 408-412.

Del Giorgio, P. A., J. M. Gasol, D. Vaqué, P. Mura, S. Agustí, AND C. M. DuARTE. 1996. Bacterioplankton community structure: Protists control net production and the proportion of active bacteria in a coastal marine community. Limnol. Oceanogr. 41: 1169-1179.

Ducklow, H. W., and C. A. Carlson. 1992. Oceanic bacterial productivity. Adv. Microb. Ecol. 12: 113-181.

Fenchel, T. 1986. The ecology of heterotrophic microflagellates. Adv. Microb. Ecol. 9: 57-97.

Gasol, J. M., U. L. Zweifel, F. Peters, J. A. Fuhrman, and A. Hagström. 1999. Significance of size and nucleic acid content heterogeneity as measured by flow cytometry in natural planktonic bacteria. Appl. Environ. Microbiol. 65: 4475-4483.

Granéli, E., And J. T. Turner. 2002. Top-down regulation in ctenophore-copepod-ciliate-diatom-phytoflagellate communities in coastal waters: A mesocosm study. Mar. Ecol. Prog. Ser. 239: 57-68.

Grasshoff, K., K. Kremling, and M. Erhardt. 1999. Methods of seawater analysis, 3rd ed. Wiley-VCH.

Henjes, J., P. Assmy, C. Klaas, P. Verity, and V. Smetacek. 2007. Response of microzooplankton (protists and small copepods) to an iron-induced phytoplankton bloom in the Southern Ocean (EisenEx). Deep-Sea Res. I 54: 363-384.

Hirche, H.-J., T. Brey, And B. Niehoff. 2001. A high-frequency time series at Ocean Weather Ship Station M (Norwegian Sea): Population dynamics of Calanus finmarchicus. Mar. Ecol. Prog. Ser. 219: 205-219.

Hoppe, H. G. 1993. Use of fluorogenic model substrates for extracellular enzyme activity (EEA) measurement of bacteria, p. 423-431. In P. F. Kemp, B. F. Sherr, E. B. Sherr and J. J. Cole [eds.], Handbook of methods in aquatic microbial ecology. Lewis.

JürgENS, K. 1994. Impact of Daphnia on planktonic microbial food webs - a review. Mar. Microb. Food Webs 8: 295-324.

- H. Arndt, And K. O. Rothhaupt. 1994. Zooplanktonmediated changes of bacterial community structure. Microb. Ecol. 27: 27-42.

—, AND C. Matz. 2002. Predation as a shaping force for the phenotypic and genotypic composition of planktonic bacteria. Antonie Van Leeuwenhoek 81: 413-434.

Kiørboe, T. 1997. Population regulation and role of mesozooplankton in shaping marine pelagic food webs. Hydrobiologia 363: $13-27$

Kivi, K., And O. SETÄLÄ. 1995. Simultaneous measurement of food particle selection and clearance rates of planktonic oligotrich ciliates (Ciliophora: Oligotrichina). Mar. Ecol. Prog. Ser. 119: 125-137.

Levinsen, H., J. T. Turner, T. G. Nielsen, and B. W. Hansen. 2000. On the trophic coupling between protists and copepods in arctic marine ecosystems. Mar. Ecol. Prog. Ser. 204: 65-77.

LOREAU, M., AND OTHERS. 2001. Biodiversity and ecosystem functioning: Current knowledge and future challenges. Science 294: 804-808.

Marion, P. V. 1996. Ecological studies in Hogavågen, a landlocked bay at Agdenes, Sør-Trøndelag, Norway. Gunneria 71: 1-39.
McQueen, D., M. Johannes, J. Post, T. Stewart, and D. R. S LEAN. 1989. Bottom-up and top-down impacts on freshwater pelagic community structure. Ecol. Monogr. 59: 289-309.

Mikola, J., AND H. SeTÄlä. 1998. No evidence of trophic cascades in an experimental microbial-based soil food web. Ecology 79: 153-164.

Møller, E. F., P. Thor, and T. G. Nielsen. 2003. Production of DOC by Calanus finmarchicus, C. glacialis and C. hyperboreus through sloppy feeding and leakage from fecal pellets. Mar. Ecol. Prog. Ser. 262: 185-191.

ØvreÅs, L., AND OTHERs. 2003. Response of bacterial and viral communities to nutrient manipulations in seawater mesocosms. Aquat. Microb. Ecol. 31: 109-121.

Pace, M. L., J. J. Cole, S. R. Carpenter, and J. F. Kitchell. 1999. Trophic cascades revealed in diverse ecosystems. Trends Ecol. Evol. 14: 483-488.

Pauly, D., V. Christensen, J. Dalsgatrd, R. Froese, and F. TORres, JR. 1998. Fishing down marine food webs. Science 279: $860-863$.

Perez, M. T., J. R. Dolan, and E. Fukai. 1997. Planktonic oligotrich ciliates in the NW Mediterranean: Growth rates and consumption by copepods. Mar. Ecol. Prog. Ser. 155: 89-101.

Persson, L. 1999. Trophic cascades: Abiding heterogeneity and the trophic level concept at the end of the road. Oikos 85: 385-397.

Polis, G. A., A. L. W. Sears, G. R. Huxel, D. R. Strong, and J. Maron. 2000. When is a trophic cascade a trophic cascade? Trends Ecol. Evol. 15: 473-475.

Reinthaler, T., C. Winter, and G. J. Herndl. 2005. Relationship between bacterioplankton richness, respiration, and production in the Southern North Sea. Appl. Environ. Microbiol. 71: 2260-2266.

Rivkin, R. B., and L. Legendre. 2002. Roles of food web and heterotrophic microbial processes in upper ocean biogeochemistry: Global patterns and processes. Ecol. Res. 17: $151-159$.

Saiz, E., and A. Calbet. 2007. Scaling of feeding in marine calanoid copepods. Limnol. Oceanogr. 52: 668-675.

SAnders, R. W., and S. A. Wickham. 1993. Planktonic protozoa and metazoa: Predation, food quality and population control. Mar. Microb. Food Webs 7: 197-223.

SchÄFer, H., AND G. Muyzer. 2001. Denaturing gradient gel electrophoresis in marine microbial ecology. Methods Microbiol. 30: 425-468.

Schauer, M., R. Massana, and C. Pedrós-Alió. 2000. Spatial differences in bacterioplankton composition along the Catalan coast (NW Mediterranean) assessed by molecular fingerprinting. FEMS Microbiol. Ecol. 33: 51-59.

Schnetzer, A., And D. A. Caron. 2005. Copepod grazing impact on the trophic structure of the microbial assemblage of the San Pedro Channel, California. J. Plankton Res. 27: 959-971.

Sheldon, R. W., P. Nival, and F. Rassoulzadegan. 1986. An experimental investigation of a flagellate-ciliate-copepod food chain with some observations relevant to the linear biomass hypothesis. Limnol. Oceanogr. 31: 184-188.

Sherr, B. F., E. B. Sherr, and R. D. Fallon. 1987. Use of monodispersed fluorescently labeled bacteria to estimate in situ protozoan bacterivory. Appl. Environ. Microbiol. 53: 958-965.

AND J. MCDANIEL. 1992. Effect of protistan grazing on the frequency of dividing cells in bacterioplankton assemblages. Appl. Environ. Microbiol. 58: 2381-2385.

Sherr, E. B., AND B. F. SHerr. 2002. Significance of predation by protists in aquatic microbial food webs. Antonie Van Leeuwenhoek 81: 293-308. 
SHuRin, J. B., AND OTHERS. 2002. A cross-ecosystem comparison of the strength of trophic cascades. Ecol. Lett. 5: 785-791.

Šmek, K., J. Nedoma, J. Pernthaler, T. Posch, and J. R. Dolan. 2002. Altering the balance between bacterial production and protistan bacterivory triggers shifts in freshwater bacterial community composition. Antonie Van Leeuwenhoek 81: 453-463.

Sipura, J., E. Lores, And R. A. Snyder. 2003. Effect of copepods on estuarine microbial plankton in short-term microcosms. Aquat. Microb. Ecol. 33: 181-190.

Sommer, U., AND F. Sommer. 2006. Cladocerans versus copepods: The cause of contrasting top-down controls on freshwater and marine phytoplankton. Oecologia 147: 183-194.

,-- H. Feuchtmayr, and T. Hansen. 2004. The influence of mesozooplankton on phytoplankton nutrient limitation: A mesocosm study. Protist 155: 295-304.

—, AND H. STiBor. 2002. Copepoda-Cladocera-Tunicata: The role of three major mesozooplankton groups in pelagic food webs. Ecol. Res. 17: 161-174.

Stibor, H., AND others. 2004. Copepods act as a switch between alternative trophic cascades in marine pelagic food webs. Ecol. Lett. 7: 321-328.

Strong, D. 1992. Are trophic cascades all wet? Differentiation and donor-control in speciose ecosystems. Ecology 73: 747-754.

Sundt-Hansen, L. E., Y. Olsen, H. Stibor, M. Heldal, and O. VADSTEIN. 2006. Trophic cascades mediated by copepods, not nutrient supply rate, determine the development of picocyanobacteria. Aquat. Microb. Ecol. 45: 207-218.
Thingstad, T. F. 2000. Control of bacterial growth in idealized food webs, p. 229-259. In D. L. Kirchman [ed.], Microbial ecology of the oceans. Wiley.

Verity, P. G., and V. Smetacek. 1996. Organism life cycles, predation, and the structure of marine pelagic ecosystems. Mar. Ecol. Prog. Ser. 130: 277-293.

Weinbauer, M. G., and F. Rassoulzadegan. 2004. Are viruses driving microbial diversification and diversity? Environ. Microbiol. 6: 1-11.

Wickнam, S. A. 1998. The direct and indirect impact of Daphnia and Cyclops on a freshwater microbial food web. J. Plankton Res. 20: 739-755. , AND U. G. Berninger. 2007. Krill larvae, copepods and the microbial food web: Interactions during the Antarctic fall. Aquat. Microb. Ecol. 46: 1-13.

Zöllner, E., B. Santer, M. Boersma, H. G. Hoppe, and K. JürgENS. 2003. Cascading predation effects of Daphnia and copepods on microbial food web components. Freshw. Biol. 48: $2174-2193$.

Zubkov, M. V., AND A. López-Urrutia. 2003. Effect of appendicularians and copepods on bacterioplankton composition and growth in the English Channel. Aquat. Microb. Ecol. 32: 39-46..

Edited by: Michael L. Landry

Received: 18 February 2008 Accepted: 04 August 2008 Amended: 21 August 2008 